\title{
Source apportionment of carbonaceous aerosol in southern Sweden
}

\author{
J. Genberg ${ }^{1}$, M. Hyder ${ }^{2}$, K. Stenström ${ }^{1}$, R. Bergström ${ }^{3,4}$, D. Simpson ${ }^{5,6}$, E. O. Fors ${ }^{1}$, J. Å. Jönsson ${ }^{2}$, and E. Swietlicki ${ }^{1}$ \\ ${ }^{1}$ Department of Physics, Lund University, P.O. Box 118, 22100, Lund, Sweden \\ ${ }^{2}$ Department of Chemistry, Lund University, P.O. Box 124, 22100, Lund, Sweden \\ ${ }^{3}$ Department of Chemistry, University of Gothenburg, 41296, Gothenburg, Sweden \\ ${ }^{4}$ Swedish Meteorological and Hydrological Institute, 60176, Norrköping, Sweden \\ ${ }^{5}$ EMEP MSC-W, Norwegian Meteorological Institute, P.O. Box 43, 0313 Oslo, Norway \\ ${ }^{6}$ Department of Earth \& Space Sciences, Chalmers University of Technology, 41296, Gothenburg, Sweden
}

Received: 8 April 2011 - Published in Atmos. Chem. Phys. Discuss.: 4 May 2011

Revised: 25 October 2011 - Accepted: 27 October 2011 - Published: 16 November 2011

\begin{abstract}
A one-year study was performed at the Vavihill background station in southern Sweden to estimate the anthropogenic contribution to the carbonaceous aerosol. Weekly samples of the particulate matter $\mathrm{PM}_{10}$ were collected on quartz filters, and the amounts of organic carbon, elemental carbon, radiocarbon $\left({ }^{14} \mathrm{C}\right)$ and levoglucosan were measured. This approach enabled source apportionment of the total carbon in the $\mathrm{PM}_{10}$ fraction using the concentration ratios of the sources. The sources considered in this study were emissions from the combustion of fossil fuels and biomass, as well as biogenic sources. During the summer, the carbonaceous aerosol mass was dominated by compounds of biogenic origin $(80 \%)$, which are associated with biogenic primary and secondary organic aerosols. During the winter months, biomass combustion (32\%) and fossil fuel combustion $(28 \%)$ were the main contributors to the carbonaceous aerosol. Elemental carbon concentrations in winter were about twice as large as during summer, and can be attributed to biomass combustion, probably from domestic wood burning. The contribution of fossil fuels to elemental carbon was stable throughout the year, although the fossil contribution to organic carbon increased during the winter. Thus, the organic aerosol originated mainly from natural sources during the summer and from anthropogenic sources during the winter. The result of this source apportionment was compared with results from the EMEP MSC-W chemical transport model. The model and measurements were generally consistent for total atmospheric organic carbon, however, the contribution of the sources varied substantially. E.g. the biomass burning contributions of OC were underestimated by the model by a factor of 2.2 compared to the measurements.
\end{abstract}

Correspondence to: J. Genberg

(johan.genberg@nuclear.lu.se)

\section{Introduction}

Aerosol particles are known to have adverse effects on human health (Dockery et al., 1993) by affecting not only the respiratory tract, but also the cardiovascular organs (Pope III et al., 2002). Aerosol particles also influence the Earth's climate due to their optical properties and their ability to act as condensation nuclei for cloud droplets (Andreae et al., 2004). Aerosol composition must, therefore, be taken into consideration when modelling changes in the Earth's climate. However, it is not known in detail how human activities affect aerosol composition, or the degree to which they can alter the climate.

According to aerosol mass spectrometry measurements performed in Europe, the organic aerosol (OA) constitutes a considerable fraction of the submicron particle mass, corresponding to between 30 and $60 \%$ of the aerosol mass, depending on location and season (Jimenez et al., 2009). The large fraction of organic compounds in aerosol particles motivates studies of these compounds because of their adverse effects on our environment. Also, the sources of these particles are highly uncertain and variable (Gelencsér et al., 2007; May et al., 2009). Organic aerosols originate mainly from three sources: combustion of fossil fuels, biomass burning and biogenic sources. All these sources can contribute to both primary and secondary organic aerosols (POAs and SOAs). Biogenic POAs consist of pollen and plant debris, fungal spores and microorganisms. Biogenic SOAs originate from volatile organic compounds (VOCs) emitted by plants, e.g. monoterpenes. The emission of biogenic VOCs is related to the growing season and temperature, and is significantly greater during the warmer months of the year (Zemankova and Brechler, 2010). Primary fossilfuel-based emissions from traffic and industry contribute to organic aerosols, as do secondary particles arising from the

Published by Copernicus Publications on behalf of the European Geosciences Union. 
emission of fossil-based VOCs. Biomass burning, e.g. forest fires, is common during dry periods and is a large contributor to aerosol particles globally (Crutzen and Andreae, 1990) and occasionally in Nordic areas (Saarikoski et al., 2008). The burning of biomass for domestic heating is also a major source of particles, especially in South Asia (Gustafsson et al., 2009), but also in some European cities e.g. Zurich (Switzerland), where approximately $65 \%$ of the winter carbonaceous aerosol has been found to originate from biomass burning (Szidat et al., 2006). During wintertime biomass burning is also a large contributor to aerosol mass in the Scandinavian countries; Sweden (Hedberg Larsson et al., 2006; Szidat et al., 2009), Denmark (Glasius et al., 2006) and Norway (Yttri et al., 2009, 2011b).

The carbonaceous aerosol consists of numerous compounds with different chemical and physical properties. The total carbon content (TC) is divided into organic carbon (OC) and elemental carbon (EC). The organic carbon fraction includes organic molecules and polymers, e.g. cellulose, alkanes and organic acids, which do not absorb visible light. EC contains compounds with graphite-like structures formed during combustion, e.g. char and soot, which can absorb light (Pöschl, 2005). This means that EC has important climate impact, as light-absorbing particles heats the atmosphere (Menon et al., 2002). The heating effect of EC on the climate may regionally be as large as that of carbon dioxide (Ramanathan and Carmichael, 2008). The split of combustion products into $\mathrm{OC}$ and $\mathrm{EC}$ is, however, not clear as they form a continuum from OC to EC (Masiello, 2004). With higher combustion temperatures, carbon compounds generally become more light absorbing and less reactive, all properties of EC. Numerous methods of separating OC from EC by thermal analysis have been proposed (Cachier et al., 1989; Fung, 1990). These methods utilise the difference in thermal stability between OC and EC. However, during the analysis, some organic compounds char due to heating and form "false" EC. This can be corrected for by monitoring the transmission of a laser beam through the filter sample during heating. The NIOSH protocol (Birch and Cary, 1996) uses this transmission method which is also the basis for the protocol developed within the EU-funded project EUSAAR (European Supersites for Atmospheric Aerosol Research) (Cavalli et al., 2010).

Radiocarbon $\left({ }^{14} \mathrm{C}\right)$ is a powerful tracer for modern carbon. With a half-life of $5730 \mathrm{yr},{ }^{14} \mathrm{C}$ is depleted in fossil fuels while present at traceable amounts in carbon from contemporary sources. The amount of ${ }^{14} \mathrm{C}$ in a sample can therefore be used to determine the fractions of carbon with modern and fossil origin. However, the $\mathrm{F}^{14} \mathrm{C}$-value of atmospheric $\mathrm{CO}_{2}$ has been altered the last century by the release of ${ }^{14} \mathrm{C}$ from detonations of thermonuclear weapons in the 1950s and 1960s (the bomb effect, Rafter and Fergusson, 1957), as well as dilution of atmospheric modern $\mathrm{CO}_{2}$ by fossil carbon emitted from combustion of fossil fuels (the Suess effect, Suess, 1955). These changes have to be taken into account when using ${ }^{14} \mathrm{C}$ as a tracer of modern carbon. ${ }^{14} \mathrm{C}$ has been used in several aerosol source apportionment studies to determine the influence of fossil fuels on the organic aerosol (e.g. Szidat et al., 2006, 2007; Gelencsér et al., 2007). Since both the biogenic OA and the biomass burning carbonaceous aerosol contain ${ }^{14} \mathrm{C}$, it is difficult to separate these two sources by relying solely on carbon isotope measurements. The tracer molecule levoglucosan can however be used to determine whether the particles originate from the burning of biomass, as it is formed when cellulose is heated to above $300^{\circ} \mathrm{C}$. For the purpose of this study, levoglucosan was considered to be atmospherically stable, although this is still being debated (Locker, 1988; Fraser and Lakshmanan, 2000; Hoffmann et al., 2010).

In this study, 51 aerosol samples collected in southern Sweden over one year were analysed to determine the concentrations of ${ }^{14} \mathrm{C}$, levoglucosan, EC and OC. These measurements were combined to provide the first full-year source apportionment of the carbonaceous aerosol in Sweden with a similar methodology used in previous studies (e.g. Gelencsér et al., 2007; Szidat et al., 2006; Yttri et al., 2011a, b). The measurement based source apportionment results for OC were compared with corresponding results from the EMEP MSC-W chemical transport model. This is an important step to evaluate how well the OA models and their input data represent the measurements.

\section{Methods}

\subsection{Sampling}

The sampling site Vavihill is a EUSAAR and EMEP (European Monitoring and Evaluation Programme) background station situated in southern Sweden $\left(56^{\circ} 01^{\prime} \mathrm{N}, 13^{\circ} 09^{\prime} \mathrm{E}\right.$, $172 \mathrm{~m}$ a.s.l.). The station is not close to any large local pollution sources, although the distances to the densely populated areas of Malmö, Copenhagen and Helsingborg, west to southwest of the station, are only 45,50 and $25 \mathrm{~km}$, respectively. Continental Europe in the south also influences the air at Vavihill, whereas air masses from the north and northeast are generally clean (Kristensson et al., 2008).

Samples were collected weekly between April 2008 and April 2009. The $\mathrm{PM}_{10}$ fraction was collected on $47 \mathrm{~mm}$ quartz filters (Pall Tissuquartz ${ }^{\mathrm{TM}}$, binder-free) using an aerosol flow of $381 \mathrm{~min}^{-1}$. The filters were baked at $900^{\circ} \mathrm{C}$ for $4 \mathrm{~h}$ prior to sampling. After sampling, the filters were stored in a Petri dish, wrapped in aluminium foil in a refrigerator $\left(+8^{\circ} \mathrm{C}\right)$ or a freezer $\left(-30^{\circ} \mathrm{C}\right)$. Samples were generally analysed for OC and EC within 12 weeks of sampling. ${ }^{14} \mathrm{C}$ and levoglucosan analyses were conducted within two years of sampling.

Most of the samples were collected using the EUSAAR sampling train, consisting of two filters in series following a VOC denuder in order to remove VOCs. Some samples 
were collected without the use of the denuder and therefore the $\mathrm{OC}$ values had to be corrected for positive artefacts due to adsorbed VOCs. Samples collected with the denuder were not corrected for positive or negative artefacts since the backfilter loadings were close to that of the field blanks, indicating that the artefacts were low. These back-filter results also demonstrate that storage of the filters did not lead to any significant positive artefacts. Two tests were performed at Vavihill to determine the denuder efficiency in order to estimate positive artefacts; one in February 2008 and one in August 2008. Samples were collected simultaneously in three sampling lines: one with both a denuder and a Teflon filter in front of two quartz filters, one with only a Teflon filter in front of two quartz filters, and one with two quartz filters without a denuder or a Teflon filter. The results from these samples were in this study used to evaluate the magnitude of the positive artefacts on samples collected without a denuder.

\section{$2.2 \mathrm{OC} / \mathrm{EC}$ analysis}

OC/EC analyses were conducted on a $0.5 \mathrm{~cm}^{2}$ area of the filter using a DRI Model 2001 OC/EC Carbon Analyzer (Atmoslytic, Calabasas, CA, USA). The organic and elemental carbon fractions were separated according to a novel method developed within the framework of the EUSAAR project called the EUSAAR_2 protocol. This was developed to reduce measurement uncertainty in aerosol samples from background sites around Europe (Cavalli et al., 2010). According to the EUSAAR_2 protocol, the filter sample is heated in helium in four steps to $650{ }^{\circ} \mathrm{C}$. The filter is then left to cool to $500^{\circ} \mathrm{C}$, oxygen $(2 \%)$ is added and the temperature is raised in four steps to $850^{\circ} \mathrm{C}$. The split point between OC and EC is determined by monitoring the transmission of a laser beam through the filter $(\mathrm{He} / \mathrm{Ne}, 633 \mathrm{~nm})$. When the transmission reaches its initial value, i.e. the value of the start of the analysis, the carbon left on the filter is regarded as EC.

\section{$2.3{ }^{14} \mathrm{C}$ determination}

The ${ }^{14} \mathrm{C}$ content in the aerosol samples was analysed using accelerator mass spectrometry. Prior to analysis, the carbon was extracted using a newly implemented graphitisation system optimised for $\mu \mathrm{g}$-sized samples (Genberg et al., 2010). Briefly, the sample is combusted in vacuum using $\mathrm{CuO}$ as oxidation agent. The $\mathrm{CO}_{2}$ formed is cryogenically purified and mixed with $\mathrm{H}_{2}$ in a small-volume reduction reactor, and thereafter heated to $600^{\circ} \mathrm{C}$. In the reaction, the $\mathrm{CO}_{2}$ is transformed into pure graphite on a heated iron catalyst. The ${ }^{14} \mathrm{C} /{ }^{12} \mathrm{C}$ ratio in the graphite is analysed using the $250 \mathrm{kV}$ single-stage accelerator mass spectrometer at Lund University (Skog, 2007; Skog et al., 2010) and expressed as fraction modern $\left(\mathrm{F}^{14} \mathrm{C}\right)$ (Reimer et al., 2004). The uncertainty of the measured value is determined by the ${ }^{14} \mathrm{C}$ counting statistics of the AMS run and the standard deviation of mean from repeated isotope ratio measurements of the sample, blanks and standards. $\mathrm{A} \mathrm{F}^{14} \mathrm{C}$ value of 1.0 is equivalent to the hypothetical concentration of ${ }^{14} \mathrm{C}$ in atmospheric carbon from 1950 when human influences are not taken into account. The true atmospheric ${ }^{14} \mathrm{C}$ concentration has however been altered due to emissions of fossil $\mathrm{CO}_{2}$ (Suess effect) and formation of ${ }^{14} \mathrm{C}$ from thermonuclear weapons (bomb effect).

Due to the Suess and bomb effect $\mathrm{F}^{14} \mathrm{C}$ values had to be deduced for the different modern sources of carbon (biogenic and biomass). For biogenic emissions a value of $\mathrm{F}^{14} \mathrm{C}=1.04$ was used, taken from measurements performed by Levin in 2007 (I. Levin, personal communication, 2008). It is complicated to determine the $\mathrm{F}^{14} \mathrm{C}$ of biomass burning $\left(\mathrm{F}^{14} \mathrm{C}_{\mathrm{bb}}\right)$ since the trees used as firewood in Sweden today were growing during the 1960 s, when the amount of ${ }^{14} \mathrm{C}$ in the atmosphere was up to twice that of today (Levin and Hesshaimer, 2000). We used the method described by Lewis et al. (2004) to model the amount of ${ }^{14} \mathrm{C}$ accumulated in trees. The method uses the Chapman-Richards growth model (Richards, 1959) to simulate the growth of the tree, and atmospheric ${ }^{14} \mathrm{C}$ concentrations (Stuiver and Quay, 1981; Levin et al., 2008; I. Levin, personal communication, 2008) to estimate the $\mathrm{F}^{14} \mathrm{C}$ of the whole tree. According to this method, a 60 - to 80 -yr-old tree harvested in 2008 has an estimated $\mathrm{F}^{14} \mathrm{C}$ between 1.21 and 1.23 (Fig. 1).

\subsection{Levoglucosan analysis}

Levoglucosan was analysed using the method of Zdrahal et al. (2002) with some modifications. A filter sample, $1 \mathrm{~cm}^{2}$, was further divided into small pieces and placed in a $50 \mathrm{ml}$ conical Pyrex flask. Fifteen $\mathrm{ml}$ of a solvent mixture of dichloromethane and methanol $(3: 1)$ was added to the flask. Extraction was carried out for $45 \mathrm{~min}$ in a Branson 3200 sonicator (Branson, Danbury, CT, USA). The extract was collected, and two separate aliquots of $10 \mathrm{ml}$ of the dichloromethane:methanol mixtures were added for reextraction for 30 and $15 \mathrm{~min}$. The extract was pooled and concentrated to dryness by evaporation at $60^{\circ} \mathrm{C}$ under a gentle stream of $\mathrm{N}_{2}$. Dichloromethane $\left(\mathrm{CH}_{2} \mathrm{Cl}_{2}\right)$ was added to the solid material remaining, to a volume of $1 \mathrm{ml}$.

Fifty $\mu \mathrm{l}$ of the extract solution and $5 \mu \mathrm{l}$ DTE $(1,4-$ dithioerythritol, $0.5 \mu \mathrm{g} \mathrm{ml}^{-1}$, $99 \%$ pure, Sigma-Aldrich) were placed in a gas chromatography vial and evaporated to dryness under a stream of nitrogen at $60^{\circ} \mathrm{C}$. Thirty $\mu$ pyridine (99.5\% purity, Acros Organics) and $10 \mu \mathrm{N}$-methyl-N(trimethylsilyl)trifluoroacetamide (MSTFA, $\geq 98 \%$ excluding trimethylsilyl chloride, Acros Organics) containing 1\% trimethylsilyl chloride was added to the vial. The vial was sealed with a screw cap with Teflon septa. Derivatisation was carried out at $80^{\circ} \mathrm{C}$ for one hour, after which the sample was allowed to cool to room temperature. The solution containing derivatised levoglucosan was evaporated to dryness at $60^{\circ} \mathrm{C}$ under a continuous flow of nitrogen, and thereafter dissolved in $50 \mu \mathrm{l}$ dichloromethane containing $5 \mu \mathrm{g} \mathrm{ml}^{-1} 1$ phenyldodecane (97\% Acros Organics, internal standard). 


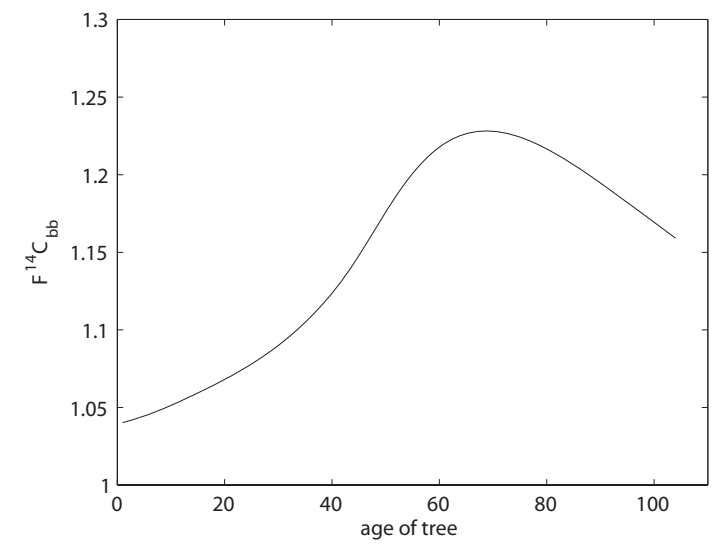

Fig. 1. Simulated $\mathrm{F}^{14} \mathrm{C}$ values for trees harvested in 2008 as a function of tree age.

Samples were analysed using an Agilent 6890 series gas chromatograph with an Agilent 5973 network mass detector. The column used was Varian VF- $1 \mathrm{~ms}(30 \mathrm{~m} \times 0.32 \mathrm{~mm}$ ID $0.25)$. The injection volume was $2 \mu \mathrm{l}$, and splitless injection was used. The inlet temperature was $280^{\circ} \mathrm{C}$ and constant flow mode was used. The gas $(\mathrm{He})$ flow through the column was $1.3 \mathrm{ml} \mathrm{min}^{-1}$. The temperature programme was as follows: initial temperature $60^{\circ} \mathrm{C}$ for three minutes, the temperature was then raised to $190^{\circ} \mathrm{C}$ at a rate of $10^{\circ} \mathrm{C} \mathrm{min}^{-1}$, and finally the temperature was raised to $300^{\circ} \mathrm{C}$ at a rate of $30^{\circ} \mathrm{C} \mathrm{min}^{-1}$ (Hsu et al., 2007). The MSD transfer line temperature was $280^{\circ} \mathrm{C}$, the MS source temperature was $250^{\circ} \mathrm{C}$, and the MS quadropole temperature was $180^{\circ} \mathrm{C}$. The samples were extracted, derivatised and injected using duplicates, i.e. every sample was injected 8 times. Levoglucosan was identified by comparison with the mass spectrum and retention time of standards, and quantified using selected-ion monitoring. The amount of levoglucosan was quantified using $m / z=217$, and 1-phenyldodecane (internal standard) using $m / z=246$. Standards were prepared using $99 \%$ pure 1.6anhydro- $\beta$-glucopyranose (Alfa Aesar).

\subsection{Source apportionment method}

To model the origin of the carbon fractions, the carbon was assumed to originate from one of three sources: biogenic emissions, biomass burning and combustion of fossil fuels. These are the same sources as those used by Szidat et al. (2006). The total carbon (TC) content is divided into OC and EC:

$\mathrm{TC}=\mathrm{EC}+\mathrm{OC}$

EC is determined as the sum of elemental carbon arising from biomass burning $\left(\mathrm{EC}_{\mathrm{bb}}\right)$ and fossil fuel combustion $\left(\mathrm{EC}_{\mathrm{ff}}\right)$ :

$\mathrm{EC}=\mathrm{EC}_{\mathrm{ff}}+\mathrm{EC}_{\mathrm{bb}}$
$\mathrm{EC}_{\mathrm{bb}}$ is calculated using the measured levoglucosan concentration (lev) and the estimated ratio of $\mathrm{EC}_{\mathrm{bb}} / \mathrm{lev}$ :

$\mathrm{EC}_{\mathrm{bb}}=\mathrm{lev} \cdot \frac{\mathrm{EC}_{\mathrm{bb}}}{\mathrm{lev}}=\mathrm{lev} \cdot\left(\frac{\mathrm{EC}}{\mathrm{OC}}\right)_{\mathrm{bb}} /\left(\frac{\mathrm{lev}}{\mathrm{OC}_{\mathrm{bb}}}\right)$

The ratio $\mathrm{EC}_{\mathrm{bb}} / \mathrm{lev}$ is determined using two ratios from earlier studies (Sect. 2.6): (EC/OC) $)_{b b}$ and (lev/OC limited so as not to exceed the total measured $\mathrm{EC}$, to prevent negative values of $\mathrm{EC}_{\mathrm{ff}}$. $\mathrm{EC}_{\mathrm{ff}}$ is then determined by subtraction (Eq. 2).

$\mathrm{OC}$ is separated into three sources: biomass burning $\left(\mathrm{OC}_{\mathrm{bb}}\right)$, biogenic $\mathrm{OC}\left(\mathrm{OC}_{\mathrm{bio}}\right)$ and $\mathrm{OC}$ originating from fossil fuels $\left(\mathrm{OC}_{\mathrm{ff}}\right)$ :

$\mathrm{OC}=\mathrm{OC}_{\mathrm{bb}}+\mathrm{OC}_{\mathrm{bio}}+\mathrm{OC}_{\mathrm{ff}}$

$\mathrm{OC}_{\mathrm{bb}}$ includes primary particles emitted from forest fires and agricultural clearing, as well as domestic wood burning and is based on the formation of levoglucosan when cellulose is heated during the combustion. $\mathrm{OC}_{\text {bio }}$ in this study includes both primary and secondary biogenic particles, as well as secondary particles formed from other non-fossil sources, i.e. SOA originating from biomass burning.

$\mathrm{OC}_{\mathrm{bb}}$ is calculated using the levoglucosan levels (lev) and the levoglucosan to $\mathrm{OC}_{\mathrm{bb}}$ ratio (lev/OC $\mathrm{bb}$ ), which yields the organic primary particle emission from biomass burning:

$\mathrm{OC}_{\mathrm{bb}}=\mathrm{lev} / \frac{\mathrm{lev}}{\mathrm{OC}_{\mathrm{bb}}}$

Since levoglucosan is not an ideal quantitative tracer, and the lev/OC $\mathrm{bb}$ ratio is uncertain, as will be discussed in Sect. 2.6, the value of $\mathrm{OC}_{\mathrm{bb}}$ was limited in two ways in the calculations. Firstly, it was not allowed to exceed the total OC. Secondly, it was limited by the radiocarbon measurement in order not to introduce so much $\mathrm{OC}_{\mathrm{bb}}$ that the ${ }^{14} \mathrm{C}$ level could not be balanced by $\mathrm{OC}_{\mathrm{ff}}$. The maximum amount of $\mathrm{OC}$ originating from biomass burning $\left(\mathrm{OC}_{\mathrm{bb}_{\max }}\right)$ corresponds to the amount of $\mathrm{OC}$ needed to allocate all ${ }^{14} \mathrm{C}$ in the $\mathrm{OC}$ fraction to biomass burning:

$\mathrm{OC}_{\mathrm{bb}_{\max }}=\mathrm{OC} \cdot \frac{\mathrm{F}^{14} \mathrm{C}_{\mathrm{OC}}}{\mathrm{F}^{14} \mathrm{C}_{\mathrm{bb}}}$

$\mathrm{F}^{14} \mathrm{C}_{\mathrm{OC}}$ is calculated from the measured ${ }^{14} \mathrm{C}$ concentration in the sample $\left(\mathrm{F}^{14} \mathrm{C}_{\mathrm{TC}}\right)$, OC/EC measurements, and the levoglucosan value:

$\mathrm{F}^{14} \mathrm{C}_{\mathrm{OC}}=\frac{\left(\mathrm{F}^{14} \mathrm{C}_{\mathrm{TC}} \cdot \mathrm{TC}-\mathrm{F}^{14} \mathrm{C}_{\mathrm{EC}} \cdot \mathrm{EC}\right)}{\mathrm{OC}}$

In Eq. (7), $\mathrm{F}^{14} \mathrm{C}_{\mathrm{EC}}$ is determined by the relative contribution of biomass burning to EC:

$\mathrm{F}^{14} \mathrm{C}_{\mathrm{EC}}=\mathrm{F}^{14} \mathrm{C}_{\mathrm{bb}} \cdot \frac{\mathrm{EC}_{\mathrm{bb}}}{\mathrm{EC}}$

$\mathrm{F}^{14} \mathrm{C}_{\mathrm{bb}}$ is the ${ }^{14} \mathrm{C}$ concentration in wood smoke, modelled using the method described by Lewis et al. (2004) as described 
above (Sect. 2.3). The value of $\mathrm{F}^{14} \mathrm{C}_{\mathrm{OC}}$ is, however, close to the value of $\mathrm{F}^{14} \mathrm{C}_{\mathrm{TC}}$ since $\mathrm{OC}$ is the dominant contributor to the total carbon.

$\mathrm{OC}_{\text {bio }}$ is calculated by balancing the ${ }^{14} \mathrm{C}$ content which was not attributed to $\mathrm{OC}_{\mathrm{bb}}$ (Eq. 5):

$\mathrm{OC}_{\mathrm{bio}}=\frac{\mathrm{OC} \cdot \mathrm{F}^{14} \mathrm{C}_{\mathrm{OC}}-\mathrm{OC}_{\mathrm{bb}} \cdot \mathrm{F}^{14} \mathrm{C}_{\mathrm{bb}}}{\mathrm{F}^{14} \mathrm{C}_{\mathrm{bio}}}$

$\mathrm{F}^{14} \mathrm{C}_{\text {bio }}$ is the ${ }^{14} \mathrm{C}$ concentration of the atmosphere and is set to 1.04 (I. Levin, personal communication, 2008). The remaining $\mathrm{OC}$ is considered to originate from fossil fuels $\left(\mathrm{OC}_{\mathrm{ff}}\right)$ and is obtained by subtraction (Eq. 4).

\subsection{Sensitivity analysis}

Some of the variables in Eqs. (1-9) are measured and some are taken from the literature, all with uncertainties (Table 1). To evaluate the effect of the uncertainties of the different variables on the outcome of source apportionment, a random sampling model (McKay et al., 1979) inspired by the Latin hypercube sampling method (Gelencsér et al., 2007) was used. All variables were allowed to vary within a set distribution (Table 2), and calculations were performed with 3000 random sets of variables. The median value from the calculations was considered the best estimate since the mean value may be affected by the use of limitations in the calculations (Eqs. 3 and 5). A source is regarded as significant if the 5th percentile of the calculations is greater than $10 \%$ of the limit of detection (LOD) for the OC/EC analysis $\left(0.02 \mu \mathrm{g} \mathrm{m}^{-3}\right.$ for OC and $0.007 \mu \mathrm{g} \mathrm{m}^{-3}$ for EC).

The measurements of ${ }^{14} \mathrm{C}$ concentration $\left(\mathrm{F}^{14} \mathrm{C}\right)$ and levoglucosan used in the equations were allowed to vary by \pm 2 standard deviations in a broad beta distribution $(\alpha=1.5$, $\beta=1.5)$. OC and EC measurements were varied by \pm 10 and $20 \%$, respectively, in a beta distribution $(\alpha=1.5, \beta=1.5)$. The value of the ${ }^{14} \mathrm{C}$ concentration resulting from biomass combustion was modelled according to Lewis et al. (2004), as described in Sect. 2.3. In Sweden, forests are normally clear cut at an age of 60 to $80 \mathrm{yr}$, rendering an $\mathrm{F}^{14} \mathrm{C}_{\mathrm{bb}}$ value of 1.21 to 1.23 for the majority of the fire wood. However, fire wood used for domestic burning (which normally has less effective combustion) may be derived from thinning of the forest, which provides younger firewood (20-30 yr), and therefore lower $\mathrm{F}^{14} \mathrm{C}_{\mathrm{bb}}$ values (1.06 to 1.09). To cover this variation in age a broad beta distribution of $\mathrm{F}^{14} \mathrm{C}_{\mathrm{bb}}$ was used ( $\alpha=1.8, \beta=1.2$ ). This distribution slightly favours the higher values to emphasize the higher values as most of the firewood used belongs to the older category.

The ratios of levoglucosan to $\mathrm{OC}_{\mathrm{bb}}$ and $\mathrm{EC}_{\mathrm{bb}}$ to $\mathrm{OC}_{\mathrm{bb}}$ are dependent on the type of wood being burnt and the burning conditions (Oros and Simoneit, 2001a, b), which vary in the south of Sweden (and throughout Europe). Both ratios have been investigated for numerous types of wood fuels used in the US (Fine et al., 2001, 2002, 2004a, b; Engling et al., 2006). The results from these studies, together with the results presented by Zdráhal et al. (2002) are presented in Table 1. The values reported by Zdráhal et al. are from measurements in Brazil during the dry season, where most of the particulate carbon is presumed to originate from biomass burning.

Similar investigations have been performed in order to determine the best values for these ratios. Szidat (2006) concluded that suitable values of the levoglucosan/OC $\mathrm{Cb}_{\mathrm{bb}}$ and $(\mathrm{EC} / \mathrm{OC})_{\text {bb }}$ ratios were $0.15 \pm 0.09$ and $0.16 \pm 0.05$, respectively, while Gelencsér et al. (2007) used 0.08-0.167 for levoglucosan/OC $\mathrm{Cb}_{\mathrm{bb}}$ and 0.07-1.0 for $(\mathrm{EC} / \mathrm{OC})_{\mathrm{bb}}$. Puxbaum et al. (2007) used 0.136 for levoglucosan/OC $\mathrm{Cb}_{\mathrm{bb}}$ ratio after having undertaken an extensive literature survey. The ratios and distributions used in the present study for the sensitivity analysis are presented in Table 2. A uniform distribution between 0.08 and 0.2 was used as the value for the levoglucosan/ $\mathrm{OC}_{\mathrm{bb}}$ ratio, which covers most of the variation in the measurements, as well as the ratios used in previous studies. Estimates of the $(\mathrm{EC} / \mathrm{OC})_{\mathrm{bb}}$ ratio vary by more than one order of magnitude, and although the mean values are close to 0.15 , the additional uncertainty of the OC/EC ratio analyses must be taken into account. A large portion of the range of estimates given by Fine (Table 1, 0.06-0.45) were used in a broad beta distribution $(\alpha=1.12, \beta=1.52)$, which slightly favours the lower values with a maximum probability of 0.15 .

\subsection{Source apportionment model of OC}

The calculated sources based on measurements were compared with modelled sources apportionment of OC from the same time periods. A recently developed particulate carbonaceous matter (PCM) version of the EMEP MSCW chemical transport model (Simpson et al., 2007, 2011; Bergström and Simpson, 2010; Bergström et al., 2011) was used. The EMEP PCM model includes an organic aerosol scheme based on the Volatility Basis Set (VBS) approach (Donahue et al., 2006).

The emitted fossil fuel POA is distributed over different volatilities (9-bin VBS) and partitions between the gas and particulate phases. The emissions are assumed to be accompanied by emissions of low-vapour pressure (that is, partitioning) gases, which are currently not captured in either the POA or the VOC inventories. Following Shrivastava et al. (2008) the total emissions of condensable material (including POA) are assumed to amount to 2.5 times the POA inventory.

Both POA and SOA undergo gas phase reactions with $\mathrm{OH}$ (aging) and each reaction leads to a shift of the reacting OA to a lower volatility bin $\left(k_{\mathrm{OH}-\mathrm{POA}}=4 \times 10^{-11} \mathrm{~cm}^{3}\right.$ molecule $\mathrm{s}^{-1} \mathrm{~s}^{-1}, k_{\mathrm{OH}-\mathrm{SOA}}=4 \times 10^{-12} \mathrm{~cm}^{3}$ molecule $^{-1} \mathrm{~s}^{-1}$, Lane et al., 2008).

Primary organic aerosol emissions were taken from the EUCAARI anthropogenic carbonaceous aerosol emission inventory (Visschedijk et al., 2009). Other anthropogenic 
Table 1. Ratios of levoglucosan/OC $\mathrm{bb}$ and $(\mathrm{EC} / \mathrm{OC})_{\mathrm{bb}}$ from other studies.

\begin{tabular}{llllllll}
\hline \multicolumn{3}{c}{ Levoglucosan/OC } & & \multicolumn{3}{c}{$(\mathrm{EC} / \mathrm{OC})_{\mathrm{bb}}$} & \multirow{2}{*}{ Reference } \\
\cline { 1 - 2 } Minimum & Maximum & Mean & & Minimum & Maximum & Mean & \\
\hline 0.05 & 0.17 & $0.1 \pm 0.04$ & & 0.04 & 0.43 & $0.15 \pm 0.15$ & Fine et al. (2001) \\
0.036 & 0.159 & $0.1 \pm 0.05$ & & 0.08 & 0.18 & $0.13 \pm 0.05$ & Fine et al. (2002) \\
0.1 & 0.33 & $0.16 \pm 0.1$ & & 0.016 & 0.45 & $0.09 \pm 0.14$ & Fine et al. (2004a) \\
0.125 & 0.409 & $0.24 \pm 0.1$ & & 0.06 & 0.38 & $0.21 \pm 0.13$ & Fine et al. (2004b) \\
0.23 & 0.52 & $0.34 \pm 0.16$ & & 0.025 & 0.059 & $0.046 \pm 0.02$ & Schauer et al. (2001) \\
0.036 & 0.54 & $0.28 \pm 0.21$ & & - & - & - & Engling et al. (2006) \\
0.047 & 0.159 & 0.108 & - & - & 0.04 & Zdráhal et al. (2002) \\
\hline
\end{tabular}

Table 2. Parameters used in the randomised sampling simulation.

\begin{tabular}{lcccl}
\hline Parameter & Low & $\begin{array}{c}\text { Most } \\
\text { probable value }\end{array}$ & High & Distribution \\
\hline$(\mathrm{EC} / \mathrm{OC})_{\mathrm{bb}}$ & 0.06 & 0.15 & 0.45 & Beta $(\alpha=1.12, \beta=1.52)$ \\
lev/OC $\mathrm{bb}$ & 0.08 & - & 0.2 & uniform \\
$\mathrm{F}^{14} \mathrm{C}_{\mathrm{bb}}$ & 1.06 & 1.2 & 1.23 & Beta $(\alpha=1.8, \beta=1.2)$ \\
$\mathrm{OC}_{\text {factor }}$ & 0.9 & 1 & 1.1 & $\operatorname{Beta}(\alpha=1.5, \beta=1.5)$ \\
$\mathrm{EC}_{\text {factor }}$ & 0.8 & 1 & 1.2 & Beta $(\alpha=1.5, \beta=1.5)$ \\
$\mathrm{F}^{14} \mathrm{C}_{\mathrm{TC}}$ & $\bar{x}-2 \sigma$ & $\bar{x}$ & $\bar{x}+2 \sigma$ & $\operatorname{Beta}(\alpha=1.5, \beta=1.5)$ \\
Levoglucosan & $\bar{x}-2 \sigma$ & $\bar{x}$ & $\bar{x}+2 \sigma$ & $\operatorname{Beta}(\alpha=1.5, \beta=1.5)$ \\
\hline
\end{tabular}

emissions are taken from the standard EMEP emission inventory (Mareckova et al., 2009). Biogenic emissions of isoprene and monoterpenes are based on Guenther et al. (1993) and Simpson et al. (1999). A background concentration of $0.5 \mu \mathrm{g} \mathrm{m}^{-3}$ of biogenic OC is included in the model. This represents sources of OC not directly included in the emission inventories (primary biogenic, oceanic, and wildfire OC). Further details about the EMEP PCM model are given in Bergström et al. (2010, 2011).

\section{Results and discussion}

\subsection{Positive artefact correction}

Most of the samples analysed in this study were collected with a denuder in front of two quartz filters. This set-up was considered artefact-free in this study, despite the fact that some positive artefacts have been found during the EUSAAR project. The denuder tests conducted at Vavihill indicate a denuder efficiency of 90 to $95 \%$. The results from parts of the Vavihill denuder tests are presented in Table 3. The back quartz filter loading on the line without a Teflon filter corresponds well to the loading of the back filter behind Teflon collected simultaneously. This demonstrates that the positive artefact is not affected by the Teflon filter. Samples where denuders were not used were corrected by using the carbon found on the back filter in accordance with the results of tests carried out in the winter and summer of 2008 (Table 3). Cheng et al. (2009), found that correcting by a factor of one times the amount of carbon on the back filter was inadequate compared with a denuded quartz filter sample. In this study a correction factor of 2.16 was used. However, the measurements range from 1.85 to 2.61 (and one outlier at 3.84 according to Grubb's test, $P<0.05$ ). No significant difference was observed between the two seasons, thus all the samples were corrected using the same factor. The correction was only conducted on the $\mathrm{OC}$ values and not to the corresponding $\mathrm{F}^{14} \mathrm{C}$ values since direct ${ }^{14} \mathrm{C}$ measurements of the back filters failed. The $\mathrm{F}^{14} \mathrm{C}$ of the positive artefacts were in this study assumed to be equal to the $\mathrm{F}^{14} \mathrm{C}$ of the TC fractions, however, a bias of the $\mathrm{F}^{14} \mathrm{C}$ of the $\mathrm{TC}$ fractions from this assumption cannot be excluded.

\subsection{OC/EC results}

The filter analyses of OC and EC show that both fractions increased in concentration during winter compared with the summer (Fig. 2). The seasons were determined by fitting a line to daily mean temperature. Summer and winter were determined as the period where the line was above $10^{\circ} \mathrm{C}$ and below $0{ }^{\circ} \mathrm{C}$, respectively (Table 4). Spring and autumn were defined as the period between winter and summer. The amount of EC in the winter was twice that in the 
Table 3. Results from denuder tests at Vavihill in 2008. Values of $\mathrm{OC}$ are presented as $\mu \mathrm{g} \mathrm{m}^{-3}$. The filters were positioned behind a Teflon filter which removes particulate matter but not VOCs. The material collected on the filters is therefore the positive artefact from VOCs. The correction factor for undenuded filter samples was determined to be 2.16 .

\begin{tabular}{lrrr}
\hline Season & Front OC & Back OC & $\begin{array}{r}\text { Correction } \\
\text { factor }\end{array}$ \\
\hline Winter & 0.73 & 0.30 & 2.43 \\
Winter & 0.48 & 0.26 & 1.85 \\
Winter & 0.73 & 0.19 & $3.84^{*}$ \\
Summer & 0.60 & 0.23 & 2.61 \\
Summer & 0.36 & 0.18 & 2.00 \\
Summer & 0.90 & 0.46 & 1.96 \\
Summer & 0.96 & 0.44 & 2.18 \\
Summer & 0.70 & 0.34 & 2.06 \\
\hline Mean & 0.68 & 0.32 & 2.16 \\
\hline
\end{tabular}

*This sample was considered an outlier using Grubbs' test $(P<0.05)$, and was therefore not used in the calculation of the mean.

summer $\left(0.15 \mu \mathrm{g} \mathrm{m}^{-3}\right.$ vs. $\left.0.3 \mu \mathrm{g} \mathrm{m}^{-3}\right)$, which is significant $(P<0.001)$. The amount of OC was higher during the winter $(P<0.1)$, and the top value was recorded at the beginning of February $2009\left(4.4 \mu \mathrm{g} \mathrm{OC} \mathrm{m}{ }^{-3}\right)$. As can be seen in Fig. 2, the EC concentration increased already in October, and remained stable throughout the autumn and most of the winter. The OC concentration, on the other hand, was fairly stable before it peaked in a few samples collected in January and February 2009.

\section{3 ${ }^{14} \mathrm{C}$ and levoglucosan results}

The concentration of ${ }^{14} \mathrm{C}$ in the organic aerosol during the summer was generally high, as can be seen in Fig. 3a. A ${ }^{14} \mathrm{C}$ concentration between 0.9 and 1.0 , expressed as $\mathrm{F}^{14} \mathrm{C}$, means that most of the carbon is of modern origin, i.e. biogenic sources or biomass burning. The simultaneously low levoglucosan concentrations (2-12 $\mathrm{ng} \mathrm{m}^{-3}$ ) (Fig. 3b) imply that the effect of biomass burning was very low, from which it can be concluded that biogenic sources dominated during the summer. The amounts of levoglucosan in the summer were lower compared to summer measurements in Norway (Yttri et al., 2007, 2011b).

During the winter months, the amount of levoglucosan in the air peaked at more than ten times the concentration found during the summer. At the same time, the ${ }^{14} \mathrm{C}$ content in TC decreased to between 0.7 and 0.8 expressed as $\mathrm{F}^{14} \mathrm{C}$. These two observations suggest that the influence of both fossil fuel and biomass burning is increased during winter. The wintertime concentrations of levoglucosan at Vavihill are similar to what has been reported for Norwegian urban samples collected during the winter (Yttri et al., 2011b) but low compared to urban background samples (Yttri et al., 2009).
Table 4. Definition of seasons determined from a line fitted to temperature data.

\begin{tabular}{lll}
\hline Season & Start & Stop \\
\hline Spring 2008 & 24 April 2008 & 3 May \\
Summer & 3 May & 25 September \\
Autumn & 25 September & 19 December \\
Winter & 19 December & 4 March 2009 \\
Spring 2009 & 4 March & 22 April \\
\hline
\end{tabular}
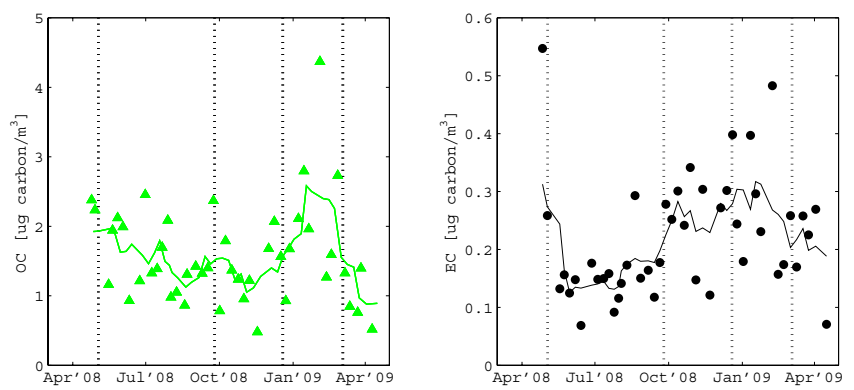

Fig. 2. Organic carbon (OC) on the left hand side and elemental (EC) carbon concentrations on the right hand side measured from filters collected at Vavihill in southern Sweden. The lines illustrate the average of the closest five points. The dotted lines represent the different seasons. Note the difference in scales in the two graphs. EC generally constitutes 10 to $15 \%$ of the total carbon, the rest being OC.

\subsection{Best estimate source apportionment}

The calculations were performed 3000 times for each filter sample, as explained in Sect. 2.6. The best estimates presented here are the median values calculated from those simulations. When discussing seasonal concentration, the mean of the given season's best estimates is used while insignificant sources' values are regarded as 0 . The differences between the sources' contributions to OC and EC and the measured $\mathrm{OC}$ or EC are in Fig. 4 attributed unapportioned OC and unapportioned EC. The results outlined above (Sects. 3.2 and 3.3) are confirmed by the best estimates, as can be seen in Fig. 4 where the seasonal sources of OC and EC are presented. The results of the sensitivity analysis are presented in Figs. 5 and 6, and will be discussed further in Sect. 3.5.

\subsubsection{Biomass burning contribution to TC}

Biomass burning only contributes slightly to the organic aerosol during the summer $(<5 \%)$, while it is the major contributor during the winter, accounting for an average of $32 \%$ of TC (Fig. 4 and Table 5). The absolute contribution of biomass burning to TC is on average about $0.79 \mu \mathrm{g} \mathrm{m}^{-3}$ during winter (Table 5). This is low compared to results from Norwegian suburban and urban background stations (Yttri et 
Table 5. Seasonal means of best estimates of source contributions, and the precision in the sources' contributions (unit: $\mu \mathrm{g} \mathrm{m}^{-3}$ ) while insignificant values are regarded as 0 . “\% of TC" represents the means of best estimates' contribution to TC.

\begin{tabular}{llrrrrrrr}
\hline Season & & $\mathrm{OC}$ & $\mathrm{EC}$ & $\mathrm{OC}_{\mathrm{bio}}$ & $\mathrm{OC}_{\mathrm{bb}}$ & $\mathrm{OC}_{\mathrm{ff}}$ & $\mathrm{EC}_{\mathrm{bb}}$ & $\mathrm{EC}_{\mathrm{ff}}$ \\
\hline \multirow{3}{*}{ Winter } & Mean & 2.19 & 0.30 & 0.43 & 0.79 & 0.69 & 0.17 & 0.05 \\
& Mean minus 1 $\sigma$ & 1.19 & 0.19 & -0.29 & 0.38 & 0.21 & 0.08 & -0.05 \\
& Mean plus $1 \sigma$ & 3.20 & 0.40 & 1.15 & 1.21 & 1.18 & 0.27 & 0.16 \\
& \% of TC & 88.1 & 11.9 & 17.2 & 31.9 & 27.8 & 7.0 & 2.2 \\
Spring & Mean & 1.13 & 0.28 & 0.77 & 0.19 & 0.14 & 0.04 & 0.23 \\
& Mean minus 1 $\sigma$ & 0.28 & 0.08 & 0.09 & 0.12 & -0.04 & 0.03 & 0.04 \\
& Mean plus 1 $\sigma$ & 1.97 & 0.47 & 1.45 & 0.26 & 0.31 & 0.06 & 0.42 \\
& \% of TC & 80.4 & 19.6 & 54.8 & 13.7 & 9.7 & 2.9 & 16.5 \\
Summer & Mean & 1.58 & 0.14 & 1.38 & 0.08 & 0.10 & 0.01 & 0.11 \\
& Mean minus 1 $\sigma$ & 1.15 & 0.11 & 1.01 & -0.02 & -0.01 & -0.01 & 0.07 \\
& Mean plus 1 $\sigma$ & 2.00 & 0.17 & 1.75 & 0.19 & 0.21 & 0.04 & 0.16 \\
& \% of TC & 91.8 & 8.2 & 80.3 & 4.9 & 5.8 & 0.8 & 6.7 \\
Autumn & Mean & 1.50 & 0.27 & 0.81 & 0.39 & 0.21 & 0.08 & 0.16 \\
& Mean minus 1 $\sigma$ & 0.98 & 0.22 & 0.15 & 0.12 & -0.03 & 0.03 & 0.06 \\
& Mean plus $1 \sigma$ & 2.02 & 0.33 & 1.48 & 0.66 & 0.44 & 0.14 & 0.26 \\
& \% of TC & 84.7 & 15.3 & 45.9 & 22.0 & 11.7 & 4.8 & 8.9 \\
\hline
\end{tabular}
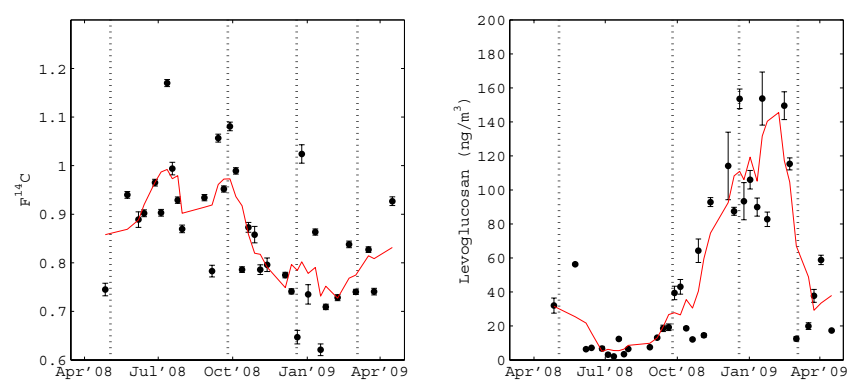

Fig. 3. ${ }^{14} \mathrm{C}$ concentration (expressed as $\mathrm{F}^{14} \mathrm{C}$ ) on the left side and levoglucosan concentration on the right. Measurements from filters collected at Vavihill from April 2008 to April 2009. The error bars illustrate one standard deviation and the red lines illustrate the average of the closest five points. The dotted lines represent the different seasons.

al., 2009), the Hungarian continental site K-Puszta (May et al., 2009) and the Portuguese site Aveiro (Gelencsér et al., 2007).

\subsubsection{Fossil contribution to TC}

The contribution to the carbonaceous aerosol from fossil fuels is lower during the summer than in the winter, while best estimates of EC resulting from fossil fuel combustion are rather stable throughout the year (Fig. 6). This leads to a varying OC/EC ratio of the fossil carbon from approximately 1 in the summer to $>5$ in the winter. This could be explained by the lower temperature in the winter altering the gas-particle equilibrium and thus suggests that a larger portion of the fossil OC during winter is secondary aerosol. It

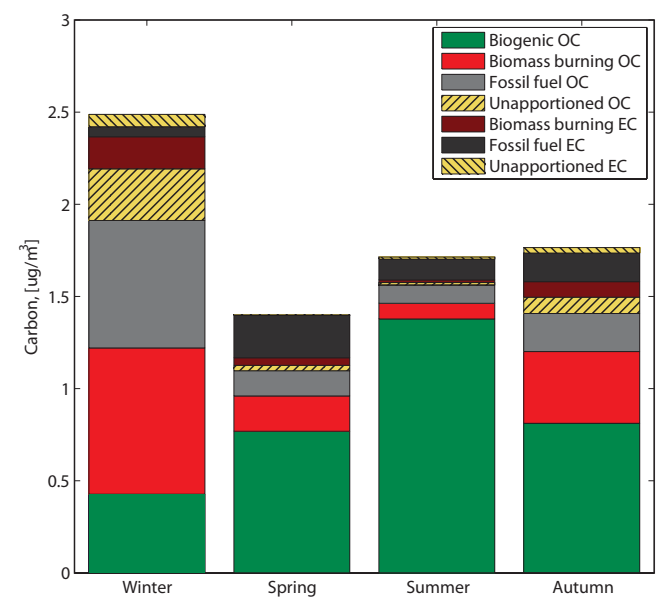

Fig. 4. Absolute contributions to the total carbon from the five sources investigated: biogenic OC, biomass burning OC and EC, and fossil fuel OC and EC. The seasonal means of the best estimates from the sensitivity analyses (Table 5) were used in the diagram. The striped parts are carbon fractions which could not be apportioned by the used method.

could also indicate a seasonal change in fossil fuel sources of the organic aerosol over the year. In this study, no method to distinguish between different fossil sources was applied.

The determination of fossil influence on TC is relying on the ${ }^{14} \mathrm{C}$ concentration of the sample. The lower $\mathrm{F}^{14} \mathrm{C}$ found in the winter cannot be interpreted as anything else but increased influence by fossil fuels. 

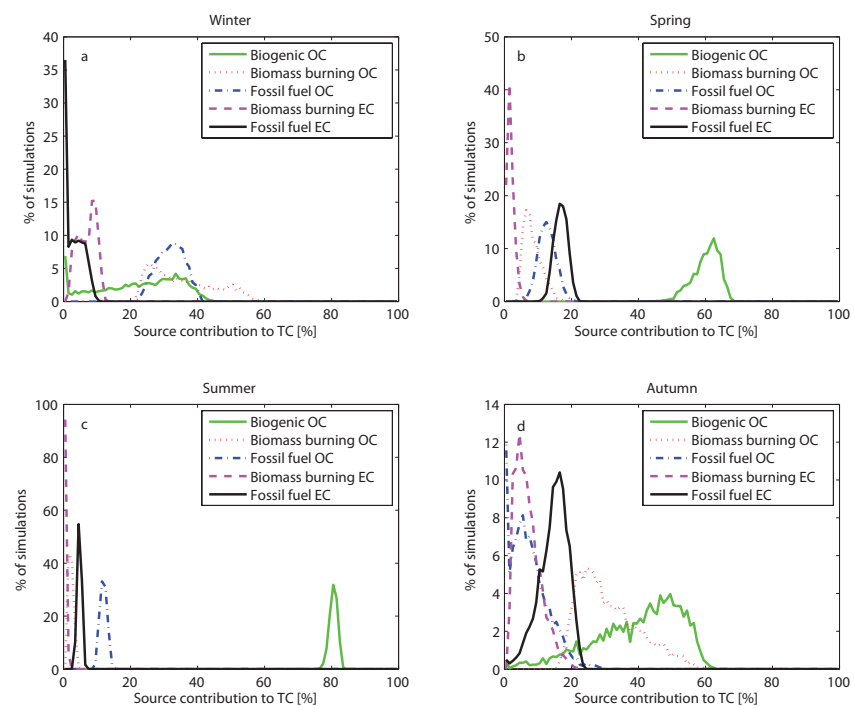

Fig. 5. Results from the sensitivity analyses of the source contributions of OC and EC as probability distributions. Each figure represents one representative filter sample from each season, (a) winter (3-11 February 2009), (b) spring (24-28 April 2008), (c) summer (28 July-1 August 2008) and (d) autumn (24-31 October 2008). The lines correspond to all the outcome of the simulation for the contribution of each source to TC.

\subsubsection{Biogenic contribution to $\mathrm{TC}$}

$\mathrm{OC}_{\mathrm{bio}}$ is, as expected, higher during summer than in winter. In the summer, $80 \%$ of the total carbon in the organic aerosol is of biogenic origin, and is due to SOA from biogenic VOCs and primary particles, e.g. pollen. However, even in the coldest months, the model attributes on average $17 \%$ of TC to biogenic sources. There may be several reasons why biogenic OC is found during the winter when most plants in Sweden are dormant. One reason could be long-range transport of biogenic SOAs or VOCs from the European continent, where VOCs are emitted during the winter months. However, the winter emission of monoterpene in central Europe is estimated to be only about $20 \%$ of the summer peak (Zemankova and Brechler, 2010), and therefore emissions alone cannot fully explain why the biogenic organic aerosol in southern Sweden during the winter is one third of the summer concentration. Increased condensation may be a factor, with colder temperature driving the semivolatile organic compounds (SVOCs) into the particle phase. Such a possibility was demonstrated by Simpson et al. (2007) but as noted there, there are too few measurements to verify or falsify such effects. Another explanation could be that the source apportionment method used here does not separate secondary OC form by precursors emitted by biomass burning from non-anthropogenic sources of $\mathrm{OC}_{\mathrm{bio}}$. Some of the carbon, which according to the model originates from biogenic sources, may thus be SOA formed from VOCs emitted by the burning of wood or biofuels e.g. ethanol combustion.
This would further increase the effect of biomass burning on the organic aerosol mass loading during the winter.

\subsection{Results of the sensitivity analysis}

Figure 5 shows the results of the sensitivity analyses for four samples representing the four seasons. Each source of carbon in the sample is illustrated as a probability distribution. The lines represent the contribution of each of the sources to TC in that individual sample. The spread in the results increases drastically with increasing influence of biomass burning, i.e. during the winter, when the levoglucosan levels are higher. This is most prominent for the source apportionment of EC, since both of the most uncertain parameters, lev/OC $\mathrm{bb}$ and $(\mathrm{EC} / \mathrm{OC})_{\mathrm{bb}}$, are being used (Table 2). Both these parameters are dependent on the burning conditions and the type of biomass in question, as discussed in Sect. 2.6. The highly uncertain source apportionment of EC can be seen in the winter sample in Fig. 5a where fossil sources are estimated to contribute to between 0 to almost $100 \%$ of EC. The use of levoglucosan as a tracer for biomass combustion is also affected by its atmospheric stability. In a recent publication, the modelled chemical half-life for levoglucosan was found to be between 72 and $84 \mathrm{~h}$ in winter conditions (Hoffmann et al., 2010). This estimate is lower than values reported earlier (Locker, 1988; Fraser and Lakshmanan, 2000), which indicates a further uncertainty in source apportionment based on levoglucosan. More reliable data would be obtained if ${ }^{14} \mathrm{C}$ analyses could be performed on the pure EC fractions of the samples. In this study, the OC and EC were not separated prior to ${ }^{14} \mathrm{C}$ analysis, although this has been done in earlier studies (Szidat et al., 2004, 2006). Separating OC and $\mathrm{EC}$ has the advantage that the EC resulting from biomass burning is not dependent on the levoglucosan values. It also allows the OC from biomass burning to be calculated from both levoglucosan values and the $(\mathrm{OC} / \mathrm{EC})_{\mathrm{bb}}$ ratio. The considerable uncertainty in source apportionment during periods with high levoglucosan values demonstrates the importance of separating $\mathrm{OC}$ and $\mathrm{EC}$ prior to ${ }^{14} \mathrm{C}$ analysis. However, no reliable technique for this separation was available at the time of this study. During periods of low levoglucosan concentrations, e.g. the summer sample in Fig. 5c, the source apportionment uncertainty is much smaller, which shows the low uncertainty in the non-biomass burning related factors used in the calculations.

Figure 6 shows the result of the total sensitivity analysis where the best estimates (median values of the 3000 calculations) are presented as diamonds and the error bars represent 5th and 95th percentiles of the simulation results. The unfilled diamonds represent source contribution where at least $5 \%$ of the 3000 calculations are below $10 \%$ of the LOD calculated from the OCEC analyser ( 0.02 for OC and 0.007 for EC) and not considered significant. As shown in Fig. 5, the uncertainties of all components are higher when levoglucosan is found in the samples. However, the data 

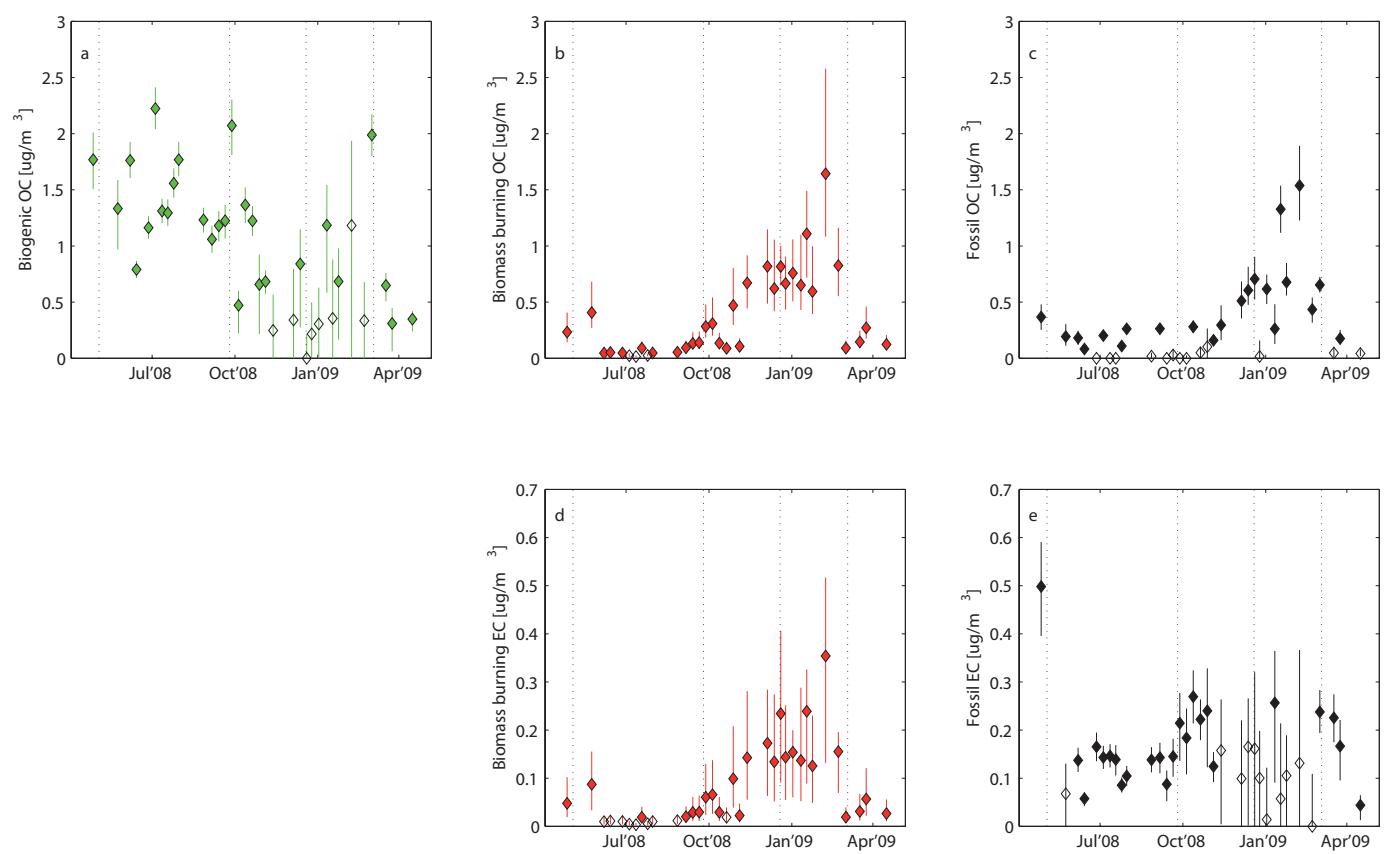

Fig. 6. Full results from the sensitivity analysis, (a) biogenic OC, (b) biomass burning OC, (c) fossil OC, (d) biomass burning EC, (e) fossil EC. The diamonds represent the median of the simulation results and the error bars represent 5th and 95th percentiles. Open diamonds represent source contribution which is not regarded as statistically significant.

show conclusively that the increase in EC during the winter is mainly due to biomass burning, while the influence of fossil fuel combustion on EC is more stable over the year. It is also evident that $\mathrm{OC}_{\mathrm{ff}}$ increases during the winter, based on ${ }^{14} \mathrm{C}$ data.

\subsection{Model comparison}

The calculated sources of $\mathrm{OC}$ were compared with results from the EMEP PCM model (Fig. 7). The modelled total $\mathrm{OC}$ and the measurements of OC coincide well although the model tends to underestimate the OC, especially for winter and autumn (Fig. 7a).

The model underestimates the biomass burning OC by a factor of about two compared to the measurements, as an average for the whole year (Fig. 7b). This underestimation is especially important for the winter samples where levoglucosan levels, and thus biomass burning OC, are high. The underestimation can be due to large-scale problems in the emission inventory or to some local wood-burning activities near the measurement site, which are not captured in the regional scale EMEP model. The biofuel emission factors, used in the emission inventory, are much lower for Sweden than for the neighbouring countries (Nielsen et al., 2010). This discrepancy can partly explain the model's underestimation of total OC during winter and autumn.

Similar problems, with too low modelled biomass burning OC, were found by Simpson et al. (2007) for other sites in Europe. Following Simpson et al. (2007), we have in-
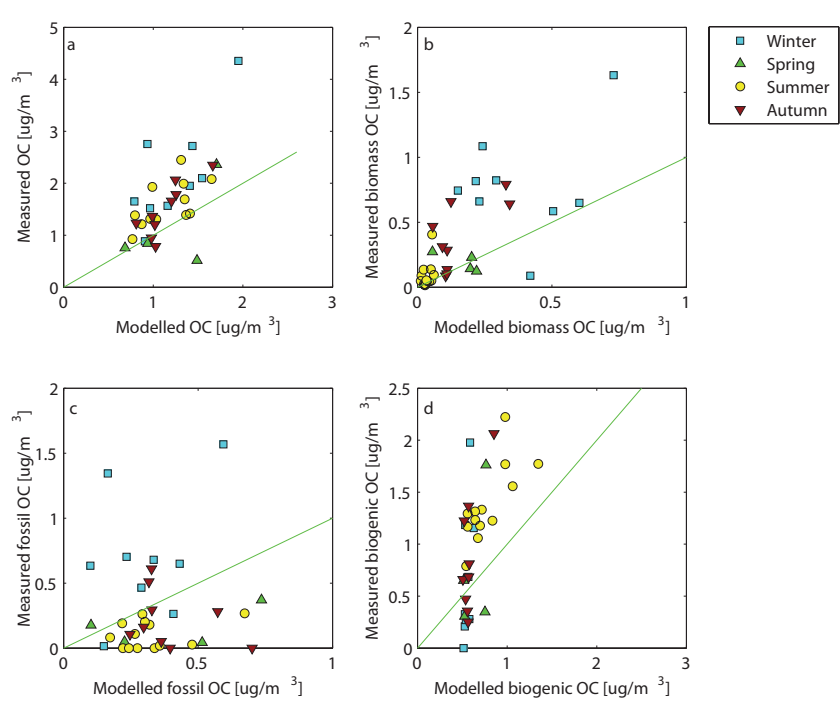

Fig. 7. Comparison between modelled (x-axis) and best estimates (y-axis) contribution to OC. Each figure represents one or more sources of OC: (a) total OC, (b) biomass burning OC, (c) fossil OC and (d) biogenic OC. The green lines represent the 1:1 lines.

vestigated the possible importance of improving the woodburning emission estimate by making a simple rescaling of the modelled biomass burning OC, using the yearly average ratio between observed and modelled concentrations of $\mathrm{OC}_{\mathrm{bb}}$ (i.e. increasing the modelled biomass burning $\mathrm{OC}$ by a factor 
of 2.2), and looked at the impact on total OC. Without rescaling, the model underestimates total OC by about $27 \%$ and the correlation coefficient between observed and modelled OC is 0.68 . Rescaling the modelled biomass burning OC leads to a smaller bias for total OC $(-17 \%)$ and also better correlation $(r=0.72)$. This suggests that improvements in the national wood burning emission inventory may be an important step towards more accurate modelling of carbonaceous aerosol. Measurements at other sites, and higher resolution modelling, are needed to determine if the emission estimates are too low in general or if it is a local scale problem.

The fossil contributions to OC in the EMEP model consist of anthropogenic SOA and primary OC emissions from fossil fuel combustion. For the summer period the model systematically overestimated fossil OC compared to the measurements (Fig. 7c). However for most of the winter and some autumn samples the fossil OC is underestimated. It should be noted that although ${ }^{14} \mathrm{C}$ measurements from a filter are precise, the possibility of contamination with "hot-carbon" (carbon containing much higher concentration than found in the atmosphere) exists close to nuclear installations, facilities for incineration of low-level radioactive waste and anthropogenic activities using ${ }^{14} \mathrm{C}$ as a tracer, and this would lead to an overestimation of the biogenic sources (Bench et al., 2007; Stenström et al., 2010). Contamination of the samples to imply a higher fossil influence is only possible if large amounts of fossil carbon were added to the samples, which would appear as elevated TC values. A more likely explanation for the incorrect seasonal variation of the model fossil OC is that the emissions of primary OC may be overestimated in summer and under-estimated in winter. Given the paucity of experimental verification of such emissions, and the myriad and seasonally differing sources of OC, such uncertainties are not surprising.

In summer the modelled biogenic contributions to OC, which are generally the largest fraction of TC, are reasonably well correlated with observations, but the model underpredicts biogenic OC by up to a factor of about two (Fig. 7d). This level of agreement is however well within the uncertainties of the emissions of BVOC (Simpson et al., 1999; Rinne et al., 2009). In this comparison the model's biogenic SOA and background OC is considered to be biogenic OC. Most of the model background $\mathrm{OC}$ is assumed to originate from primary biogenic particles, but it also includes particles emitted from the ocean and wild fires. For winter and autumn, the correlation between the model and the measurements of biogenic OC is rather high $(r=0.63)$. However, the results strongly deviate from the $1: 1$ line. This is probably partly due to the very simplified model treatment of the background $\mathrm{OC}$, which dominates the models biogenic OC during these periods. The discrepancy may also be related to errors in the measured biogenic OC. During winter, when wood burning is an important source of OC, the measured biogenic OC fraction is dependent on the highly uncertain conversion factors used to calculate $\mathrm{OC}_{\mathrm{bb}}$ from levoglucosan concentrations.

\section{Conclusions}

The sources of carbonaceous aerosol particles in background air in southern Sweden change significantly with the seasons. During summer, the total carbon is dominated by biogenic sources of OC, while fossil fuel combustion is the predominant source of EC. In winter, OC and EC originate mainly from biomass burning, as well as fossil fuel combustion. These findings are similar to those found in earlier studies. Gelencsér et al. (2007) reported similar results for the low altitude sites K-Puszta (Hungary) and Aveiro (Portugal), although those summer aerosols were not as dominated by biogenic sources as at Vavihill. Just as for Vavihill, the winter samples collected at K-Puszta and Aveiro were dominated by biomass burning. The fractions are similar at the continental and Swedish sites, although the TC mass is substantially higher at the continental sites. The present study shows that the sources of carbonaceous aerosols in southern Sweden are similar to those at other low altitude sites in Europe. This study adds a full year of source apportionment of carbonaceous aerosols at a part of Europe where such data are previously unavailable.

Comparison between the measurements and the EMEP model showed good agreement for total OC, except for the winter period. However, the model and measurement do not agree to which extent the individual sources of OC contribute. Biomass burning is a large source during winter according to the measurements, with contributions about two times larger than that suggested by the model. This indicates a strong underestimation of some Swedish and possibly international biomass burning emissions. When the biomass burning contribution in the model was scaled to fit the measured $\mathrm{OC}_{\mathrm{bb}}$ concentration, the total $\mathrm{OC}$ estimation was improved as well. Fossil sources are also underestimated by the model during winter while they are overestimated during summer. More work is needed to resolve the remaining discrepancy between measurements and models of organic aerosols, both regarding the models and the measurement based source apportionment. An important area for future work is evaluation and improvement of emission inventories of carbonaceous aerosols, especially for wood-burning and biogenic emissions of particles and VOCs.

Acknowledgements. This work was supported by The Swedish Research Council "Formas", The Swedish Clean Air Program (SCARP), the EU I3 project EUSAAR, Lund University Centre for Studies of Carbon Cycle and Climate Interactions (LUCCI), the EU 6th Framework Programme EUCAARI project (contract 036833-2), as well as by Cooperative Programme for Monitoring and Evaluation of the Long-Range Transmission of Air Pollutants in Europe (EMEP) and The Royal Physiographic Society in Lund.

Edited by: V.-M. Kerminen 


\section{References}

Andreae, M. O., Rosenfeld, D., Artaxo, P., Costa, A. A., Frank, G. P., Longo, K. M., and Silva-Dias, M. A. F.: Smoking Rain Clouds over the Amazon, Science, 303, 1337-1341, 2004.

Bench, G., Fallon, S., Schichtel, B., Malm, B., and McDade, C.: Relative contributions of fossil and contemporary carbon sources to $\mathrm{PM}_{2.5}$ aerosols at nine Interagency Monitoring for Protection of VIsual Environments (IMPROVE) network sites, J. Geophys. Res.-Atmos., 112, D10205, doi:10.1029/2006JD007708, 2007.

Bergström, R. and Simpson, D.: Organic aerosol modelling in EMEP: Recent Developments Transboundary Particulate Matter in Europe, The Norwegian Institute for Air Research (NILU), Kjeller, Norway, 54-58, 2010.

Bergström, R., Denier van der Gon, H., Prevot, A., Yttri, K. E., and Simpson, D.: Modelling Organic Aerosols in Europe with the EMEP model: Experiments with the VBS Approach, in preparation, 2011.

Birch, M. E. and Cary, R. A.: Elemental carbon-based method for monitoring occupational exposures to particulate diesel exhaust, Aerosol Sci. Technol., 25, 221-241, 1996.

Cachier, H., Bremond, M.-P., and Buat-Ménard, P.: Determination of atmospheric soot carbon with a simple thermal method, Tellus B, 41B, 379-390, doi:10.1111/j.1600-0889.1989.tb00316.x, 1989.

Cavalli, F., Viana, M., Yttri, K. E., Genberg, J., and Putaud, J.P.: Toward a standardised thermal-optical protocol for measuring atmospheric organic and elemental carbon: the EUSAAR protocol, Atmos. Meas. Tech., 3, 79-89, doi:10.5194/amt-3-79-2010, 2010.

Cheng, Y., He, K. B., Duan, F. K., Zheng, M., Ma, Y. L., and Tan, J. H.: Positive sampling artifact of carbonaceous aerosols and its influence on the thermal-optical split of OC/EC, Atmos. Chem. Phys., 9, 7243-7256, doi:10.5194/acp-9-7243-2009, 2009.

Crutzen, P. J. and Andreae, M. O.: Biomass Burning in the Tropics: Impact on Atmospheric Chemistry and Biogeochemical Cycles, Science, 250, 1669-1678, doi:10.1126/science.250.4988.1669, 1990.

Dockery, D. W., Pope, C. A., Xu, X., Spengler, J. D., Ware, J. H., Fay, M. E., Ferris, B. G., and Speizer, F. E.: An Association between Air Pollution and Mortality in Six U.S. Cities, New Engl. J. Med., 329, 1753-1759, doi:10.1056/NEJM199312093292401, 1993.

Donahue, N. M., Robinson, A. L., Stanier, C. O., and Pandis, S. N.: Coupled partitioning, dilution, and chemical aging of semivolatile organics, Environ. Sci. Technol., 40, 2635-2643, doi:10.1021/es052297c, 2006.

Engling, G., Carrico, C. M., Kreidenweis, S. M., Collett Jr, J. L., Day, D. E., Malm, W. C., Lincoln, E., Min Hao, W., Inuma, Y., and Herrmann, H.: Determination of levoglucosan in biomass combustion aerosol by high-performance anion-exchange chromatography with pulsed amperometric detection, Atmos. Environ., 40, 299-311, doi:10.1016/j.atmosenv.2005.12.069, 2006.

Fine, P. M., Cass, G. R., and Simoneit, B. R. T.: Chemical characterization of fine particle emissions from fireplace combustion of woods grown in the northeastern United States, Environ. Sci. Technol., 35, 2665-2675, 2001.

Fine, P. M., Cass, G. R., and Simoneit, B. R. T.: Organic compounds in biomass smoke from residential wood combustion: Emissions characterization at a continental scale, J. Geophys. Res.-Atmos.,
107, 8349, doi:10.1029/2001JD000661, 2002.

Fine, P. M., Cass, G. R., and Simoneit, B. R. T.: Chemical Characterization of Fine Particle Emissions from the Fireplace Combustion of Wood Types Grown in the Midwestern and Western United States, Environ. Eng. Sci., 21, 387-409, 2004a.

Fine, P. M., Cass, G. R., and Simoneit, B. R. T.: Chemical characterization of fine particle emissions from the wood stove combustion of prevalent United States tree species, Environ. Eng. Sci., 21, 705-721, 2004b.

Fraser, M. P. and Lakshmanan, K.: Using levoglucosan as a molecular marker for the long-range transport of biomass combustion aerosols, Environ. Sci. Technol., 34, 4560-4564, 2000.

Fung, K.: Particulate Carbon Speciation by $\mathrm{MnO}_{2}$ Oxidation, Aerosol Sci. Technol., 12, 122-127, 1990.

Gelencsér, A., May, B., Simpson, D., Sánchez-Ochoa, A., Kasper-Giebl, A., Puxbaum, H., Caseiro, A., Pio, C., and Legrand, M.: Source apportionment of PM2.5 organic aerosol over Europe: Primary/secondary, natural/anthropogenic, and fossil/biogenic origin, J. Geophys. Res.-Atmos., 112, 1-12, doi:10.1029/2006JD008094, 2007.

Genberg, J., Stenström, K., Elfman, M., and Olsson, M.: Development of Graphitization of $\mu \mathrm{g}$-Sized Samples at Lund University, Radiocarbon, 52, 1270-1276, 2010.

Glasius, M., Ketzel, M., Wåhlin, P., Jensen, B., Mønster, J., Berkowicz, R., and Palmgren, F.: Impact of wood combustion on particle levels in a residential area in Denmark, Atmos. Environ., 40, 7115-7124, doi:10.1016/j.atmosenv.2006.06.047, 2006.

Guenther, A. B., Zimmerman, P. R., Harley, P. C., Monson, R. K., and Fall, R.: Isoprene and monoterpene rate variability: model evaluations and sensitivity analyses, J. Geophys. Res.-Atmos., 98, 12609-12617, 1993.

Gustafsson, Ö., Krusa, M., Zencak, Z., Sheesley, R. J., Granat, L., Engstrom, E., Praveen, P. S., Rao, P. S. P., Leck, C., and Rodhe, H.: Brown Clouds over South Asia: Biomass or Fossil Fuel Combustion?, Science, 323, 495-498, doi:10.1126/science.1164857, 2009.

Hedberg Larsson, E., Johansson, C., Johansson, L., Swietlicki, E., and Brorström-Lundén, E.: Is Levoglucosan a Suitable Quantitative Tracer for Wood Burning? - Comparison with Receptor Modeling on Trace Elements in Lycksele, Sweden, J. Air Waste Manage., 56, 1669-1678, 2006.

Hoffmann, D., Tilgner, A., Iinuma, Y., and Herrmann, H.: Atmospheric Stability of Levoglucosan: A Detailed Laboratory and Modeling Study, Environ. Sci. Technol., 44, 694-699, doi:10.1021/es902476f, 2010.

Hsu, C.-L., Cheng, C.-Y., Lee, C.-T., and Ding, W.-H.: Derivatization procedures and determination of levoglucosan and related monosaccharide anhydrides in atmospheric aerosols by gas chromatography-mass spectrometry, Talanta, 72, 199-205, doi:10.1016/j.talanta.2006.10.018, 2007.

Jimenez, J. L., Canagaratna, M. R., Donahue, N. M., Prevot, A. S. H., Zhang, Q., Kroll, J. H., DeCarlo, P. F., Allan, J. D., Coe, H., Ng, N. L., Aiken, A. C., Docherty, K. S., Ulbrich, I. M., Grieshop, A. P., Robinson, A. L., Duplissy, J., Smith, J. D., Wilson, K. R., Lanz, V. A., Hueglin, C., Sun, Y. L., Tian, J., Laaksonen, A., Raatikainen, T., Rautiainen, J., Vaattovaara, P., Ehn, M., Kulmala, M., Tomlinson, J. M., Collins, D. R., Cubison, M. J., Dunlea, J. E., Huffman, J. A., Onasch, T. B., Alfarra, M. R., Williams, P. I., Bower, K., Kondo, Y., Schneider, J., Drewnick, 
F., Borrmann, S., Weimer, S., Demerjian, K., Salcedo, D., Cottrell, L., Griffin, R., Takami, A., Miyoshi, T., Hatakeyama, S., Shimono, A., Sun, J. Y., Zhang, Y. M., Dzepina, K., Kimmel, J. R., Sueper, D., Jayne, J. T., Herndon, S. C., Trimborn, A. M., Williams, L. R., Wood, E. C., Middlebrook, A. M., Kolb, C. E., Baltensperger, U., and Worsnop, D. R.: Evolution of Organic Aerosols in the Atmosphere, Science, 326, 1525-1529, doi:10.1126/science.1180353, 2009.

Kristensson, A., Dal Maso, M., Swietlicki, E., Hussein, T., Zhou, J., Kerminen, V. M., and Kulmala, M.: Characterization of new particle formation events at a background site in Southern Sweden: relation to air mass history, Tellus B, 60, 330-344, doi:10.1111/j.1600-0889.2008.00345.x, 2008.

Lane, T. E., Donahue, N. M., and Pandis, S. N.: Simulating secondary organic aerosol formation using the volatility basis-set approach in a chemical transport model, Atmos. Environ., 42, 7439-7451, doi:10.1016/j.atmosenv.2008.06.026, 2008.

Levin, I. and Hesshaimer, V.: Radiocarbon - a unique tracer of global carbon cycle dynamics, Radiocarbon, 42, 69-80, 2000.

Levin, I., Hammer, S., Kromer, B., and Meinhardt, F.: Radiocarbon observations in atmospheric $\mathrm{CO} 2$ : Determining fossil fuel $\mathrm{CO}_{2}$ over Europe using Jungfraujoch observations as background, Sci. Total Environ., 391, 211-216, doi:10.1016/j.scitotenv.2007.10.019, 2008.

Lewis, C. W., Klouda, G. A., and Ellenson, W. D.: Radiocarbon measurement of the biogenic contribution to summertime PM-2.5 ambient aerosol in Nashville, TN, Atmos. Environ., 38, 6053-6061, doi:10.1016/j.atmosenv.2004.06.011, 2004.

Locker, H. B.: The use of levoglucosan to assess the environmental impact of residential wood-burning on air quality, Thesis (Ph.D), Hanover, NH (US); Dartmouth College, 147 pp., 1988.

Mareckova, K., Wankmueller, R., Anderl, M., Poupa, S., and Wieser, M.: Inventory Review 2009. Emission Data reported under the LRTAP Convention and NEC Directive. Stage 1 and 2 review. Status of gridded data and LPS dataISBN 978-3-99004038-6, 2009.

Masiello, C. A.: New directions in black carbon organic geochemistry, Mar. Chem., 92, 201-213, doi:10.1016/j.marchem.2004.06.043, 2004.

May, B., Wagenbach, D., Hammer, S., Steier, P., Puxbaum, H., and Pio, C.: The anthropogenic influence on carbonaceous aerosol in the European background, Tellus B, 61, 464-472, 2009.

McKay, M. D., Beckman, R. J., and Conover, W. J.: A Comparison of Three Methods for Selecting Values of Input Variables in the Analysis of Output from a Computer Code, Technometrics, 21, 239-245, 1979.

Menon, S., Hansen, J., Nazarenko, L., and Luo, Y.: Climate effects of black carbon aerosols in China and India, Science, 297, 22502253, 2002.

Nielsen, O.-K., Illerup, J. B., Kindbom, K., Saarinen, K., Aasestad, K., Hallsdottir, B., Winther, M., Sjodin, Å., Makela, K., and Mikkola-Pusa, J.: Review, improvement and harmonisation of the Nordic particulate matter air emission inventories, National environmental research institute, Aarhus NERI Technical Report no. $809,77,2010$.

Oros, D. R. and Simoneit, B. R. T.: Identification and emission factors of molecular tracers in organic aerosols from biomass burning Part 1. Temperate climate conifers, Appl. Geochem., 16, 1513-1544, doi:10.1016/s0883-2927(01)00021-x, 2001a.
Oros, D. R., and Simoneit, B. R. T.: Identification and emission factors of molecular tracers in organic aerosols from biomass burning Part 2. Deciduous trees, Appl. Geochem., 16, 1545-1565, doi:10.1016/s0883-2927(01)00022-1, 2001b.

Pope III, C. A., Burnett, R. T., and Thun, M. J.: Lung Cancer, Cardiopulmonary Mortality, and Long-term Exposure to Fine Particulate Air Pollution, JAMA-J. Am. Med. Assoc., 287, 1132-1142, 2002.

Pöschl, U.: Atmospheric aerosols: Composition, transformation, climate and health effects, Angew. Chem. Int. Edit., 44, 75207540, doi:10.1002/anie.200501122, 2005.

Puxbaum, H., Caseiro, A., Sanchez-Ochoa, A., Kasper-Giebl, A., Claeys, M., Gelencser, A., Legrand, M., Preunkert, S., and Pio, C.: Levoglucosan levels at background sites in Europe for assessing the impact of biomass combustion on the European aerosol background, J. Geophys. Res.-Atmos., 112, D23S05, doi:10.1029/2006JD008114, 2007.

Rafter, T. A. and Fergusson, G. J.: "Atom Bomb Effect" - Recent Increase of Carbon-14 Content of the Atmosphere and Biosphere, Science, 126, 557-558, doi:10.1126/science.126.3273.557, 1957.

Ramanathan, V. and Carmichael, G.: Global and regional climate changes due to black carbon, Nat. Geosci., 1, 221-227, 2008.

Reimer, P. J., Brown, T. A., and Reimer, R. W.: Discussion: Reporting and Calibration of Post-Bomb ${ }^{14} \mathrm{C}$ Data, Radiocarbon, 46, 1299-1304, 2004.

Richards, F. J.: A Flexible Growth Function for Empirical Use, J. Exp. Bot., 10, 290-300, doi:10.1093/jxb/10.2.301, 1959.

Rinne, J., Bäck, J., and Hakola, H.: Biogenic volatile organic compound emissions from Eurasian taiga: Current knowledge and future directions, Boreal Environ. Res., 14, 807-826, 2009.

Saarikoski, S., Sillanpää, M., Saarnio, K., Hillamo, R., Pennanen, A., and Salonen, R.: Impact of Biomass Combustion on Urban Fine Particulate Matter in Central and Northern Europe, Water Air Soil Poll., 191, 265-277, doi:10.1007/s11270-008-9623-1, 2008.

Schauer, J. J., Kleeman, M. J., Cass, G. R., and Simoneit, B. R. T.: Measurement of Emissions from Air Pollution Sources. 3. C1C29 Organic Compounds from Fireplace Combustion of Wood, Environ. Sci. Technol., 35, 1716-1728, doi:10.1021/es001331e, 2001.

Shrivastava, M. K., Lane, T. E., Donahue, N. M., Pandis, S. N., and Robinson, A. L.: Effects of gas particle partitioning and aging of primary emissions on urban and regional organic aerosol concentrations, J. Geophys. Res.-Atmos., 113, D18301, doi:10.1029/2007jd009735, 2008.

Simpson, D., Winiwarter, W., Börjesson, G., Cinderby, S., Ferreiro, A., Guenther, A., Hewitt, C. N., Janson, R., Khalil, M. A. K., Owen, S., Pierce, T. E., Puxbaum, H., Shearer, M., Skiba, U., Steinbrecher, R., Tarrasón, L., and Öquist, M. G.: Inventorying emissions from Nature in Europe, J. Geophys. Res.-Atmos., 104D, 8113-8152, 1999.

Simpson, D., Yttri, K. E., Klimont, Z., Kupiainen, K., Caseiro, A., Gelencsér, A., Pio, C., Puxbaum, H., and Legrand, M.: Modeling carbonaceous aerosol over Europe: Analysis of the CARBOSOL and EMEP EC/OC campaigns, J. Geophys. Res.-Atmos., 112, 1-26, 2007.

Simpson, D., Gauss, M., Tsay, S. C., and Valdebenito, A.: Model Updates, in "Transboundary acidification, eutrophication and 
ground level ozone in Europe", The Norwegian Meteorological Institute, Oslo, Norway, 73-75, 2011.

Skog, G.: The single stage AMS machine at Lund University: Status report, Nucl. Instrum. Meth. B, 259, 1-6, doi:10.1016/j.nimb.2007.01.190, 2007.

Skog, G., Rundgren, M., and Sköld, P.: Status of the Single Stage AMS machine at Lund University after 4 years of operation, Nucl. Instrum. Meth. B, 268, 895-897, doi:10.1016/j.nimb.2009.10.058, 2010.

Stenström, K., Skog, G., Nilsson, C. M., Hellborg, R., Leide Svegborn, S., Georgiadou, E., and Mattsson, S.: Local variations in ${ }^{14} \mathrm{C}$ - how is bomb-pulse dating of human cells and tissues affected?, Nucl. Instrum. Meth. B, B268, 1299-1302, 2010.

Stuiver, M. and Quay, P. D.: Atmospheric ${ }^{14} \mathrm{C}$ changes resulting from fossil fuel $\mathrm{CO}_{2}$ release and cosmic ray flux variability, Earth Planet. Sc. Lett., 53, 349-362, doi:10.1016/0012821x(81)90040-6, 1981.

Suess, H. E.: Radiocarbon Concentration in Modern Wood, Science, 122, 415-417, 1955.

Szidat, S., Jenk, T. M., Gäggeler, H. W., Synal, H. A., Fisseha, R., Baltensperger, U., Kalberer, M., Samburova, V., Reimann, S., Kasper-Giebl, A., and Hajdas, I.: Radiocarbon $\left({ }^{14} \mathrm{C}\right)$-deduced biogenic and anthropogenic contributions to organic carbon (OC) of urban aerosols from Zurich, Switzerland, Atmos. Environ., 38, 4035-4044, doi:10.1016/j.atmosenv.2004.03.066, 2004.

Szidat, S., Jenk, T. M., Synal, H. A., Kalberer, M., Wacker, L., Hajdas, I., Kasper-Giebl, A., and Baltensperger, U.: Contributions of fossil fuel, biomass-burning, and biogenic emissions to carbonaceous aerosols in Zurich as traced by ${ }^{14} \mathrm{C}$, J. Geophys. Res.-Atmos., 111, D07206, doi:10.1029/2005jd006590, 2006.

Szidat, S., Prevot, A. S. H., Sandradewi, J., Alfarra, M. R., Synal, H.-A., Wacker, L., and Baltensperger, U.: Dominant impact of residential wood burning on particulate matter in Alpine valleys during winter, Geophys. Res. Lett., 34, L05820, doi:10.1029/2006GL028325, 2007.

Szidat, S., Ruff, M., Perron, N., Wacker, L., Synal, H.-A., Hallquist, M., Shannigrahi, A. S., Yttri, K. E., Dye, C., and Simpson, D.: Fossil and non-fossil sources of organic carbon (OC) and elemental carbon (EC) in Göteborg, Sweden, Atmos. Chem. Phys., 9, 1521-1535, doi:10.5194/acp-9-1521-2009, 2009.
Visschedijk, A., Denier van der Gon, H., Droge, R., and van der Brugh, A.: European high resolution and size-differentiated emission inventory for elemental and organic carbon for the year 2005, TNO, Utrecht, 2009.

Yttri, K. E., Dye, C., and Kiss, G.: Ambient aerosol concentrations of sugars and sugar-alcohols at four different sites in Norway, Atmos. Chem. Phys., 7, 4267-4279, doi:10.5194/acp-7-4267-2007, 2007.

Yttri, K. E., Dye, C., Braathen, O.-A., Simpson, D., and Steinnes, E.: Carbonaceous aerosols in Norwegian urban areas, Atmos. Chem. Phys., 9, 2007-2020, doi:10.5194/acp-9-2007-2009, 2009.

Yttri, K. E., Simpson, D., Nøjgaard, J. K., Kristensen, K., Genberg, J., Stenström, K., Swietlicki, E., Hillamo, R., Aurela, M., Bauer, H., Offenberg, J. H., Jaoui, M., Dye, C., Eckhardt, S., Burkhart, J. F., Stohl, A., and Glasius, M.: Source apportionment of the summer time carbonaceous aerosol at Nordic rural background sites, Atmos. Chem. Phys. Discuss., 11, 16369-16416, doi:10.5194/acpd-11-16369-2011, 2011a.

Yttri, K. E., Simpson, D., Stenström, K., Puxbaum, H., and Svendby, T.: Source apportionment of the carbonaceous aerosol in Norway - quantitative estimates based on ${ }^{14} \mathrm{C}$, thermal-optical and organic tracer analysis, Atmos. Chem. Phys., 11, 9375-9394, doi:10.5194/acp-11-9375-2011, 2011 b.

Zdráhal, Z., Oliveira, J., and Vermeylen, R.: Improved Method for Quantifying Levoglucosan and Related Monosaccharide Anhydrides in Atmospheric Aerosols and Application to Samples from Urban and Tropical Locations, Environ. Sci. Technol., 36, 747754, 2002.

Zemankova, K. and Brechler, J.: Emissions of biogenic VOC from forest ecosystems in central Europe: Estimation and comparison with anthropogenic emission inventory, Environ. pollut., 158, 462-469, doi:10.1016/j.envpol.2009.08.032, 2010. 